\title{
Kecenderungan dehidrasi pada remaja obesitas
}

\author{
Deny Yudi Fitranti ${ }^{1,2 *}$, Fillah Fithra Dieny ${ }^{1,2}$, Binar Panunggal ${ }^{1,2}$, Vintantiana Sukmasari ${ }^{1}$, Gardinia Nugrahani ${ }^{3}$
}

\begin{abstract}
Background: The content of water in fat cells in obese people is lower than muscle cells so that obese people are more easily dehydrated.

Objective : The purpose of this study is to determine the risk factors of dehydration in adolescents.

Methods : This study was a cross sectional study which began with screening of 168 students at SMA N 1 and 2 Semarang and found 63 students fulfilled the inclusion criteria. Subjects were selected by consecutive sampling. The dependent variable of this study is hydration status measured by the urine spesific gravity method. The independent variables consisted of obesity status that determined by the BMI/Age Z-score value, fluid intake was assessed using Semi Quantitative Food Frequency Questionnaire (SQ-FFQ), physical activity was assessed using physical activity questionnaire, whereas knowledge regarding fluid was assessed by questionnaire. Data were analyzed using Chi Square test.

Results; There were 52,4\% (n=33) subjects who were obese and only 9,5\% (n=6) subjects were well-hydrated. The incidence of dehydration in obese adolescents (63,6\%) was higher than non obese adolescents (36,7\%). Obese subjects was 1.73 times more dehydrated than non obese subjects. Subject with deficiency of fluid intake was 1,85 times more dehydrated than subject with adequate fluid intake. Knowledge regarding fluid and physical activity was not a risk factor for dehydration in adolescents.
\end{abstract}

Conclusion :Obesity and inadequate fluid intake ia risk factor for dehydration in adolescents

Keywords: urine specific gravity, hydration status, adolescent obesity, fluid intake.

\section{ABSTRAK}

Latar Belakang : kandungan air di dalam sel lemak pada orang yang mengalami obesitas lebih rendah daripada sel otot sehingga orang obese lebih mudah kekurangan cairan.

Tujuan : Penelitian ini bertujuan untuk mengetahui faktor risiko dehidrasi pada remaja

Metode : Penelitian ini adalah studi cross sectional yang diawali dengan skrining terhadap 168 siswa di SMA N 1 dan 2 Semarang dan didapatkan 63 siswa yang memenuhi kriteria insklusi dan bersedia mengikuti penelitian. Subjek dipilih menggunakan metode consecutive sampling. Variabel terikat adalah status hidrasi yang diukur berdasarkan berat jenis urin. Variabel bebas terdiri dari status obesitas yang ditentukan dengan nilai Z-Score IMT/U, konsumsi cairan yang diperoleh melalui Semi Quantitative Food Frequency Questionnaire (SQ-FFQ), aktivitas fisik yang diperoleh dari kuesioner aktivitas fisik dan pengetahuan tentang cairan yang diperoleh dari kuesioner pengetahuan. Data dianalisis menggunakan uji Chi Square.

Hasil : Terdapat 52,4\% (n=33) subjek mengalami obesitas dan hanya 9,5\% (n=6) subjek yang terhidrasi baik (wellhydrated). Kejadian dehidrasi pada remaja obesitas (63,6\%) lebih tinggi dibandingkan dengan remaja non obesitas (36,7\%). Remaja obesitas memiliki risiko 1,73 kali lebih besar mengalami dehidrasi dibandingkan dengan remaja non obesitas. Remaja dengan konsumsi cairan kurang berisiko 1,85 kali lebih besar mengalami dehidrasi dibandingkan remaja dengan konsumsi cairan yang cukup. Pengetahuan tentang cairan dan aktivitas fisik bukan merupakan faktor risiko dehidrasi pada remaja Simpulan : Obesitas dan konsumsi cairan yang kurang merupakan faktor risiko dehidrasi pada remaja.

Kata Kunci: berat jenis urin, status hidrasi, remaja obesitas, konsumsi cairan

\section{PENDAHULUAN}

Masa remaja merupakan salah satu periode rentan dalam siklus kehidupan karena terjadi perubahan hormonal, fisik, psikologis maupun sosial yang berlangsung secara cepat. Adanya proses pertumbuhan dan perkembangan yang cepat akan diikuti dengan kebutuhan zat gizi yang meningkat. Ketidakseimbangan asupan zat gizi pada remaja akan mengakibatkan terganggunya perkembangan dan pertumbuhan fisik, psikologis maupun intelektual. Asupan zat gizi tidak terkontrol juga dapat menimbulkan berbagai masalah gizi pada remaja, seperti hipertensi, hiperlipidemia, gangguan makan, anemia, overweight, dan obesitas. ${ }^{1}$

Obesitas merupakan salah satu masalah gizi pada remaja yang jumlahnya semakin meningkat setiap tahunnya. Menurut Riset Kesehatan Dasar Tahun 2010, prevalensi nasional masalah obesitas pada remaja usia 16-18 tahun sebesar 1,4\% ${ }^{2}$ meningkat menjadi 7,3\% menurut Riskesdas Tahun 2013. ${ }^{3}$ Angka kejadian ini

\footnotetext{
${ }^{1}$ Departemen Ilmu Gizi, Fakultas Kedokteran, Universitas Diponegoro. Jln. Prof Soedarto Tembalang, Semarang, Jawa Tengah 50275

${ }^{2}$ Center of Nutrition Research (CENURE) Jln Prof Soedarto Tembalang, Semarang, Jawa Tengah 50275

${ }^{3}$ Rumah Sakit Islam Sultan Agung, Jln. Kaligawe Raya Km 4, Terboyo Kulon, Genuk, Semarang, 50112

Korespondensi: E-mail : denyyudi@gmail.com, Telp/Hp : 087700065077
} 
lebih rendah bila dibandingkan dengan penelitian di Semarang pada tahun 2016. Penelitian di SMAN 2 Semarang ditemukan sebanyak $12,8 \%$ mengalami obesitas. ${ }^{4}$ Peningkatan prevalensi obesitas pada masa anak-anak akan meningkatkan risiko sindrom metabolik dan akan berisiko munculnya penyakit degeneratif, seperti penyakit kardiovaskuler ${ }^{5}$ dan dehidrasi. ${ }^{6}$

Obesitas merupakan faktor risiko dehidrasi. Terbukti dengan penelitian yang pernah dilakukan di Semarang menyebutkan bahwa remaja obesitas memiliki tingkat dehidrasi $(83,9 \%)$ lebih tinggi jika dibandingkan dengan remaja non obesitas $(51,6 \%)$. Penelitian lain di Surabaya menyebutkan angka dehidrasi lebih tinggi dibandingkan penelitian di Semarang, yaitu remaja obes $(77,8 \%)$ memiliki tingkat dehidrasi lebih tinggi dibandingkan dengan remaja non overweight $(21,6 \%)^{7}$

Remaja obesitas memiliki total air tubuh lebih rendah dibandingkan dengan remaja non obese karena kandungan air dalam sel lemak lebih rendah daripada kandungan air dalam sel otot. Remaja obese berisiko tinggi mengalami kehilangan cairan lebih banyak di banding remaja non obese. ${ }^{7}$ Penelitian terdahulu menemukan bahwa individu obes lebih banyak mengonsumsi makanan tinggi natrium yang menyebabkan retensi cairan sehingga menyebabkan dehidrasi. ${ }^{8}$

Penelitian The Indonesian Regional Hydration Study (THIRST) mengemukakan bahwa sebesar 46,1\% penduduk Indonesia mengalami dehidrasi ringan, dimana remaja memiliki tingkat dehidrasi ringan yang lebih tinggi $(49,5 \%)$ dibandingkan dewasa $(42,5 \%)$. Sebanyak $24,75 \%$ remaja di dataran tinggi dan $41,70 \%$ remaja di dataran rendah mengalami dehidrasi ringan. ${ }^{9}$ Hilangnya cairan dalam tubuh yang berlebih yang diikuti kurangnya konsumsi cairan akan menyebabkan dehidrasi. Dehidrasi yang tidak segera diatasi akan menyebabkan gangguan mood, kelelahan dan memberikan efek lemah. ${ }^{10}$

Obesitas dan dehidrasi mempunyai hubungan sebab akibat yang saling timbal balik. Banyak penelitian yang mengemukakan bahwa dehidrasi merupakan faktor risiko dari obesitas. Hal ini disebabkan karena adanya ketidakseimbangan elektrolit dalam tubuh yang memacu meningkatnya nafsu makan dan asupan makanan yang kaya lemak sehingga cairan dalam tubuh terus menurun. ${ }^{7}$ Penelitian pada remaja di perkotaan menyebutkan bahwa konsumsi cairan pada remaja obes lebih tinggi dibandingkan remaja non obes. Namun berdasarkan jenis minuman, remaja obes lebih banyak konsumsi minuman yang manis. ${ }^{6}$ Penelitian yang mengemukan sebaliknya bahwa obesitas merupakan faktor risiko dehidrasi belum banyak dilakukan. Oleh sebab itu tujuan penelitian ini adalah untuk mengetahui faktor risiko dehidrasi pada remaja obesitas.

\section{BAHAN DAN METODE}

Penelitian ini menggunakan rancangan cross sectional. Penelitian dilaksanakan pada Tahun 2016 di SMA Negeri 1 dan 2 Semarang. Populasi terjangkau pada penelitian ini adalah siswa dan siswi usia 15-17 tahun di SMA N 1 dan 2 Semarang. Berdasarkan perhitungan besar sampel minimal dengan memperhitungkan dropout $10 \%$ diperlukan 64 subjek. Populasi terjangkau pada penelitian ini adalah sejumlah 168 siswa dari SMA N 1 dan 2 Semarang . Pengambilan subjek menggunakan metode consecutive sampling.

Pengambilan subjek diawali dengan melakukan skrining terhadap siswa untuk menentukan subyek penelitian yang sesuai dengan kriteria insklusi. Kriteria inklusi dalam penelitian ini adalah tidak menderita penyakit ginjal, diabetes mellitus, diare dan bersedia menjadi subjek penelitian dengan mengisi informed consent. Kriteria eksklusi dalam penelitian ini adalah sakit atau tidak masuk sekolah pada saat penelitian dan tidak hadir saat pengambilan data. Terdapat 84 subjek yang memenuhi kriteria insklusi. Tahap selanjutnya adalah pengambilan data status hidrasi, antropometri, asupan cairan dan data karakteristik subjek melalui kuesioner. Urin tampung setelah bangun tidur dikumpulkan subjek untuk dilakukan pengukuran terhadap status hidrasi menggunakan indikator berat jenis urin (BJU). Subjek dikategorikan well-hydrated apabila berat jenis urin $<1010 \mathrm{~g} / \mathrm{ml}$, dikategorikan minimal dehydration apabila berat jenis urin 1010-1020 $\mathrm{g} / \mathrm{dl}$, dikategorikan significant dehydration apabila berat jenis urin 1020-1030 g/ml dan apabila > $1030 \mathrm{~g} / \mathrm{ml}$ dikategorikan sebagai serious dehydration. ${ }^{11}$ Pada saat analisis, variabel status hidrasi dikategorikan menjadi 2 kategori yaitu subyek dengan berat jenis urin $>1020$ $\mathrm{g} / \mathrm{ml}$ dikategorikan sebagai kelompok dehidrasi dan berat jenis urin $\leq 1020 \mathrm{~g} / \mathrm{ml}$ dikategorikan sebagai kelompok terhidrasi baik. Hanya 63 subjek yang mengembalikan urin tampung dan melengkapi data penelitian.

Variabel bebas dalam penelitian ini adalah status obesitas, konsumsi cairan, aktivitas fisik dan pengetahuan tentang cairan. Status obesitas ditentukan dengan nilai Z-Score IMT/U yang dikategorikan menjadi obese ( $>2 \mathrm{SD})$ dan non obese $(<-2$ SD sampai $>2 \mathrm{SD}) .{ }^{12}$ Pengukuran berat badan menggunakan timbangan digital dengan ketelitian $0,1 \mathrm{~kg}$ dan tinggi badan menggunakan microtoise $0,1 \mathrm{~cm}$. Asupan cairan adalah rerata jumlah total cairan yang dikonsumsi dalam sehari yang berasal dari minuman. Data konsumsi cairan didapatkan menggunakan metode semi quantitative food frequency (SQ-FFQ) meliputi jenis dan rata-rata jumlah minuman yang dikonsumsi sehari dalam seminggu terakhir. Asupan cairan dikategorikan menjadi kurang apabila konsumsi cairan kurang dari 
kebutuhan berdasarkan Angka Kecukupan Gizi 2013 yaitu $<2200 \mathrm{ml}$ untuk laki-laki dan $<2100 \mathrm{ml}$ untuk perempuan dan cukup apabila $\geq 2200 \mathrm{ml}$ untuk laki-laki dan $\geq 2100 \mathrm{ml}$ untuk perempuan. Konsumsi diuretik dapat diperoleh dari kuesioner konsumsi cairan. Konsumsi diuretik meliputi konsumsi teh, kopi dan minuman bersoda.

Aktivitas fisik diperoleh melalui kuesioner aktivitas fisik dalam sehari dengan metode recall $2 \times 24$ jam. Energi yang dikeluarkan untuk beraktivitas selama 24 jam dihitung menggunakan rumus 3,5 $\mathrm{x}$ berat badan x 5/1000 x kelipatan EMB x waktu, dimana EMB adalah kelipatan energi metabolism basal masingmasing aktivitas. Aktivitas fisik dikategorikan ringansedang apabila $\leq 3400$ kkal untuk laki-laki dan $\leq 2400$ kkal untuk perempuan dan berat apabila $>3400 \mathrm{kkal}$ untuk laki-laki dan > 2400 kkal untuk perempuan. ${ }^{12}$ Pengetahuan tentang cairan merupakan pengetahuan subyek mengenai pentingnya cairan, fungsi, sumber dan jenis cairan yang didapatkan melalui kuesioner yang terdiri dari 25 pertanyaan. Skor untuk tiap jawaban benar adalah 4 dan untuk jawaban salah adalah 0 dengan total nilai 100. Skor pengetahuan dikategorikan menjadi baik apabila skor 80-100, cukup apabila 61$<80$ dan kurang apabila skor $\leq 60$. Pada saat analisis, skor pengetahuan dikategorikan menjadi dua kategori yaitu baik bila skor 61-100 dan kurang apabila skor $\leq$ 60. Sedangkan variabel terikat pada penelitian ini adalah status hidrasi yang diukur menggunakan metode pengukuran berat jenis urin. Pemeriksaan berat jenis urin dilakukan di laboratorium menggunakan metode reagent strip.

Analisis data statistik menggunakan software komputer. Analisis univariat digunakan untuk mendeskripsikan karakteristik subjek, status hidrasi, status obesitas, konsumsi cairan, aktivitas fisik dan pengetahuan tentang cairan. Uji Chi Square digunakan untuk menganalisis besarnya faktor risiko terjadinya dehidrasi yang ditunjukkan dengan nilai RP (Rasio Prevalens).

\section{HASIL}

Jumlah subjek yang mengikuti penelitian sampai akhir sebanyak 63 subjek, yang terdiri dari 37 subjek laki-laki $(58,7 \%)$ dan 26 subjek perempuan $(41,3 \%)$. Tabel 1 menunjukkan bahwa terdapat $52,4 \% \quad(n=33)$ subjek mengalami obesitas dan hanya 9,5\% ( $\mathrm{n}=6)$ subjek yang terhidrasi baik (well-hydrated). Apabila dilihat dari konsumsi cairan, pengetahuan tentang cairan dan aktivitas fisik, sebanyak $73 \%(\mathrm{n}=46)$ subjek mengkonsumsi cukup cairan, 92,1\% (n=58) subjek mempunyai tingkat pengetahuan tentang cairan yang baik dan sebagian besar mempunyai aktivitas fisik yang ringan-sedang yaitu $73 \%(n=46)$.

Tabel 1. Distribusi Frekuensi Karakteristik Subjek Penelitian

\begin{tabular}{llll}
\hline \multicolumn{2}{c}{ Kategori variabel } & n & \% \\
\hline Jenis kelamin & Laki-laki & 37 & 58,7 \\
& perempuan & 26 & 41,3 \\
Status Obesitas & Obesitas & 33 & 52,4 \\
& Non obesitas & 30 & 47,6 \\
Konsumsi cairan & Kurang & 17 & 27 \\
& Cukup & 46 & 73 \\
Pengetahuan & Kurang & 1 & 1,6 \\
tentang cairan & Cukup & 4 & 6,3 \\
& Baik & 58 & 92,1 \\
Aktivitas Fisik & Berat & 17 & 27 \\
& Ringan-sedang & 46 & 73 \\
Status Hidrasi & Serious dehydration & 0 & 0 \\
& Significant dehydration & 32 & 50,8 \\
& Minimal dehydration & 26 & 39,7 \\
& Well-hydrated & 6 & 9,5 \\
\hline
\end{tabular}

Tabel 2. Nilai Rerata \pm SD, Minimal dan Maksimal Karakteristik Subjek Berdasarkan Status Hidrasi

\begin{tabular}{|c|c|c|c|c|c|c|}
\hline \multirow[t]{2}{*}{ Karakteristik Subjek } & \multicolumn{3}{|c|}{$\begin{array}{c}\text { Dehidrasi (BJU > } 1020 \mathrm{~g} / \mathrm{ml}) \\
\mathrm{n}=32\end{array}$} & \multicolumn{3}{|c|}{$\begin{array}{c}\text { Terhidrasi Baik }(\mathrm{BJU} \leq 1020 \mathrm{~g} / \mathrm{ml}) \\
\mathrm{n}=\mathbf{3 1}\end{array}$} \\
\hline & Rerata \pm SD & Minimal & Maksimal & Rerata \pm SD & Minimal & Maksimal \\
\hline Usia (tahun) & $15,76 \pm 0,33$ & 15 & 16 & $15,87 \pm 0,39$ & 15 & 17 \\
\hline Indeks Massa Tubuh $\left(\mathrm{Kg} / \mathrm{m}^{2}\right)$ & $28,00 \pm 5,54$ & 20,36 & 37,38 & $25,37 \pm 5,26$ & 20,24 & 39,27 \\
\hline Konsumsi cairan $(\mathrm{ml})$ & $2.198,82 \pm 623,07$ & 910 & 3.500 & $3.109,91 \pm 961,83$ & $1.770,25$ & $5.837,3$ \\
\hline Konsumsi diuretik (ml) & $353,26 \pm 218,7$ & 0 & 1.000 & $326,95 \pm 311,37$ & 0 & 1.295 \\
\hline Pengetahuan cairan (skor) & $88,88 \pm 6,8$ & 68 & 100 & $85,81 \pm 8,93$ & 52 & 96 \\
\hline Aktivitas fisik (kkal) & $1.048,21 \pm 1079,1$ & 93 & 4533 & $1.439,16 \pm 1.801,79$ & 159 & 8.640 \\
\hline
\end{tabular}

Tabel 2 menunjukkan bahwa rerata usia, skor pengetahuan tentang cairan dan aktivitas fisik pada subjek yang dehidrasi dan terhidrasi baik tidak jauh berbeda. Rerata skor pengetahuan tentang cairan pada kedua kelompok tergolong baik. Sedangkan rerata aktivitas fisik pada kedua kelompok tergolong ringan.
Konsumsi cairan pada subjek yang terhidrasi baik lebih tinggi $(3.109,91 \pm 961,83 \mathrm{ml})$ jika dibandingkan dengan remaja dehidrasi $(2.198,82 \pm 623,07 \mathrm{ml})$. Berbeda halnya dengan konsumsi cairan, konsumsi minuman diuretik lebih tinggi pada subjek dehidrasi. 
Tabel 3. Faktor Risiko Dehidrasi Pada Remaja

\begin{tabular}{|c|c|c|c|c|}
\hline \multirow[t]{3}{*}{ Variabel } & \multicolumn{2}{|c|}{ Berat Jenis Urin } & \multirow{3}{*}{$p$} & \multirow{3}{*}{$\mathbf{R P}$} \\
\hline & Dehidrasi & Terhidrasi dg baik & & \\
\hline & n (\%) & $\mathrm{n}(\%)$ & & \\
\hline \multicolumn{5}{|l|}{ Indeks Massa Tubuh } \\
\hline Obesitas & $21(63,6)$ & $12(36,4)$ & $0,032^{*}$ & 1,73 \\
\hline Non obesitas & $11(36,7)$ & $19(63,3)$ & & \\
\hline \multicolumn{5}{|l|}{ Konsumsi Cairan } \\
\hline Kurang & $13(76,5)$ & $4(23,5)$ & $0,013^{*}$ & 1,85 \\
\hline Cukup & $19(41,3)$ & $27(58,7)$ & & \\
\hline \multicolumn{5}{|l|}{ Pengetahuan Cairan } \\
\hline Kurang & $0(0,0)$ & $1(100)$ & 0,492 & 0 \\
\hline Cukup - baik & $32(51,6)$ & $30(48,4)$ & & \\
\hline \multicolumn{5}{|l|}{ Aktivitas fisik } \\
\hline Berat & $7(41,2)$ & $10(58,8)$ & 0,353 & 0,76 \\
\hline Ringan - sedang & $25(54,3)$ & $21(45,7)$ & & \\
\hline
\end{tabular}

Uji Chi Square

\section{Faktor Risiko Dehidrasi Pada Remaja}

Tabel 3 menunjukkan bahwa obesitas dan konsumsi cairan adalah faktor risiko dehidrasi pada remaja. Kejadian dehidrasi pada remaja obesitas $(63,6 \%)$ lebih tinggi jika dibandingkan dengan remaja non obesitas (36,7\%). Remaja obesitas berisiko 1,73 kali lebih besar mengalami dehidrasi dibandingkan remaja non obesitas. Hasil penelitian ini juga menyebutkan bahwa $76,5 \%$ remaja yang kurang mengonsumsi cairan, mengalami dehidrasi. Prosentase ini lebih besar dibandingkan kejadian dehidrasi pada remaja yang cukup mengonsumsi cairan $(41,3 \%)$. Remaja dengan konsumsi cairan yang kurang berisiko 1,85 kali lebih besar mengalami dehidrasi dibandingkan remaja dengan konsumsi cairan cukup. Sedangkan pengetahuan remaja tentang cairan dan aktivitas fisik bukan merupakan faktor risiko dehidrasi pada remaja.

\section{PEMBAHASAN}

Hasil penelitian ini menyebutkan bahwa $52,4 \%$ $(\mathrm{n}=33)$ subjek mengalami obesitas (Tabel 1). Angka ini lebih tinggi dibandingkan hasil penelitian pada remaja SMA di Jogjakarta yang menemukan hanya $17,7 \%$ remaja mengalami obesitas ${ }^{13}$ dan $26,33 \%$ remaja di Minahasa mengalami obesitas. ${ }^{14}$ Obesitas merupakan salah satu masalah gizi pada remaja yang jumlahnya semakin meningkat setiap tahunnya. Menurut Riset Kesehatan Dasar Tahun 2010, prevalensi nasional masalah obesitas pada remaja usia 16-18 tahun sebesar $1,4 \%{ }^{2}$ meningkat menjadi $7,3 \%$ menurut Riskesdas Tahun 2013. ${ }^{3}$

Berdasarkan berat jenis urin, status hidrasi pada remaja dalam penelitian ini dan hanya 9,5\% $(n=6)$ subjek yang terhidrasi baik (well-hydrated). Hasil ini jauh lebih rendah dari penelitian sebelumnya yang mengukur status hidrasi menggunakan kartu PURI dan mendapatkan hasil prevalensi remaja dehidrasi sebesar $32 \% .{ }^{6}$ Hal ini dikaitkan dengan konsumsi cairan pada remaja yang terhidrasi baik lebih tinggi $(3.109,91 \pm 961,83 \mathrm{ml})$ jika dibandingkan dengan remaja dehidrasi $(2.198,82 \pm 623,07 \mathrm{ml})$.

Berbeda halnya dengan konsumsi cairan, konsumsi minuman diuretik lebih tinggi pada subjek dehidrasi. Penelitian menyebutkan bahwa minuman diuretik seperti teh dan kopi berpengaruh terhadap keseimbangan cairan tubuh. ${ }^{15}$ Penelitian di Indonesia menyebutkan minuman yang paling banyak dikonsumsi selain air putih adalah teh $(32,3 \%)$, susu $(16,1 \%)$, kopi $(4,3 \%)$, minuman berkarbonasi $(8,6 \%)$, dan minuman manis lainnya. ${ }^{16}$ Minuman diuretik selama ini tidak termasuk dalam anjuran konsumsi cairan sehari ${ }^{17}$ dianjurkan menambah konsumsi cairan 1 gelas air untuk setiap konsumsi segelas kopi atau teh untuk menjaga status hidrasi. Sebagai minuman diuretic, teh, kopi atau coklat mengandung kafein. Kafein berperan sebagai adenosine reseptor antagonis untuk menurunkan reabsorbsi sodium di ginjal. Menurut suatu penelitan kafein akan bertindak sebagai diuretic bila dikonsumsi dalam dosis yang tinggi $(\geq 500 \mathrm{mg}) .{ }^{18}$ Semakin tinggi konsumsi kafein akan semakin meningkat volume urin yang dikeluarkan. Suatu penelitian lain juga menyebutkan bahwa kafein apabila dikonsumsi dalam jumlah yang moderate yaitu $4 \mathrm{mg}$ kafein / kg BB atau 4 cangkir/hari @200 ml tidak mempengaruhi status hidrasi seseorang. ${ }^{19}$

Tabel 3 menunjukkan bahwa obesitas dan konsumsi cairan adalah faktor risiko dehidrasi pada remaja. Remaja obesitas berisiko 1,73 kali lebih besar mengalami dehidrasi dibandingkan remaja non obesitas. Penelitian ini sejalan dengan penelitian sebelumnya yang menemukan bahwa $59,7 \%$ remaja obese mengalami dehidrasi dan angka ini lebih tinggi dibandingkan kejadian dehidrasi pada remaja non obese $(40,3 \%) .{ }^{20}$ Hasil ini sejalan juga dengan penelitian sebelumnya, yang menemukan bahwa dehidrasi banyak ditemukan pada remaja obesitas $(53,4 \%)$ dibandingkan remaja non obese $(46,6 \%) .{ }^{21}$ 
Remaja obesitas memiliki risiko 1,73 kali lebih besar mengalami dehidrasi dibandingkan dengan remaja non obesitas. Hasil ini memiliki nilai risiko yang lebih besar jika dibandingkan dengan penelitian Hardiansyah et al yang menyebutkan remaja obesitas memiliki risiko 1,35 kali mengalami dehidrasi. ${ }^{22} \mathrm{Hal}$ ini dapat terjadi pada obesitas, karena air tubuh total lebih rendah dibandingkan dengan orang yang tidak obesitas ${ }^{10}$, kandungan air di dalam sel lemak lebih rendah daripada kandungan air di dalam sel otot. Perbandingan antara air dan lemaknya berbanding 50\%:50\% lebih rendah dibandingkan dengan orang yang berat badannya normal sehingga orang obese lebih mudah kekurangan cairan. ${ }^{8}$ Hal ini menyebabkan orang yang obesitas mempunyai kebutuhan cairan yang lebih tinggi dibandingkan yang tidak obesitas (tergantung metabolic rate, body suface dan berat badan) dan kurangnya asupan cairan pada remaja obesitas akan semakin meningkatkan risiko kejadian dehidrasi. ${ }^{20}$

Hasil penelitian ini juga menyebutkan bahwa $76,5 \%$ remaja yang kurang mengonsumsi cairan, mengalami dehidrasi. Prosentase ini lebih besar dibandingkan kejadian dehidrasi pada remaja yang cukup mengonsumsi cairan (41,3\%). Remaja dengan konsumsi cairan yang kurang berisiko 1,85 kali lebih besar mengalami dehidrasi dibandingkan remaja dengan konsumsi cairan cukup. Air adalah komponen terbesar dari tubuh manusia dan kurang lebih 55\% tubuh remaja adalah air tergantung dari usia jenis kelamin dan persen lemak tubuh. Remaja dengan status hidrasi baik lebih banyak mengkonsumsi cairan dibandingkan remaja dengan status hidrasi kurang. ${ }^{23}$ Suatu penelitian menyebutkan bahwa seluruh remaja obese yang ikut serta dalam penelitian tersebut mempunyai asupan cairan diatas rekomendasi dan semua terhidrasi baik. ${ }^{24}$

Hasil penelitian ini sesuai dengan penelitian yang dilakukan pada beberapa kelompok remaja, kelompok remaja yang tidak mengonsumsi cairan sebelum latihan mengalami dehidrasi lebih berat (rerata berat jenis urin :1026 $\pm 0,0005$ ) dibandingkan dengan remaja yang mengonsumsi minuman sebelum latihan (rerata berat jenis urin : 1021 \pm 0,0006). ${ }^{25}$ Kebutuhan asupan cairan setiap orang berbeda, hal ini dapat ditentukan oleh beberapa hal, diantaranya, asupan makanan, aktivitas fisik, suhu dan kelembapan lingkungan. Air memiliki banyak fungsi dalam tubuh, diantaranya menjaga keseimbangan cairan sel tubuh. Asupan cairan yang tidak terpenuhi dapat menyebabkan ketidakseimbangan kandungan cairan yang dikonsumsi dan cairan yang dikeluarkan oleh tubuh, sehingga dapat meningkatkan risiko dehidrasi. ${ }^{10}$

Penelitian ini menunjukkan bahwa skor pengetahuan tentang cairan pada remaja yang mengalami dehidrasi maupun yang terhidrasi baik sebagian besar tergolong baik. Hasil penelitian ini sama dengan penelitian sebelumnya yang menemukan bahwa semua subjek remaja mempunyai pengetahuan yang baik tentang cairan. Tingginya paparan informasi melalui media televisi dan media sosial khususnya pada remaja di perkotaan merupakan salah satu penyebab tingginya pengetahuan pada remaja. ${ }^{6}$ Rerata aktivitas fisik pada remaja tergolong rendah baik pada kelompok dehidrasi maupun yang terhidrasi baik yaitu $<1500$ kkal. Seberapa banyak cairan yang kita konsumsi tergantung pada jenis aktivitas dan berapa lama aktivitas tersebut dilakukan. Beraktivitas yang berat dalam waktu yang lama dan pada suhu lingkungan panas dapat menyebabkan kehilangan cairan tubuh sebanyak $2 \mathrm{~L} /$ jam melalui keringat, dan dapat menyebabkan dehidrasi. ${ }^{11}$

Pengetahuan tentang cairan dan aktivitas fisik bukan merupakan faktor risiko dehidrasi pada remaja. Hasil penelitian ini sejalan dengan penelitian di Banten yang menyebutkan bahwa tidak terdapat perbedaan signifikan antara pengetahuan cairan pada remaja yang terhidrasi baik dan remaja yang kurang terhidrasi. ${ }^{26}$ Menurut penelitian Hardiansyah et al pengetahuan yang baik dapat mempengaruhi asupan cairan, baik dalam segi kuantitas maupun kualitas dalam kehidupan seharihari. Pengetahuan yang baik akan mendorong individu untuk memilki kebiasaan minum yang lebih baik. ${ }^{22}$ Namun pengetahuan yang cukup akan cairan belum tentu merubah perilaku dalam mengonsumsi cairan sehari-hari. Perilaku sangat dipengaruhi oleh sikap dan lingkungan dimana orang tersebut berada. Penelitian yang dilakukan berdasarkan data The Indonesian Hydration Study (THIRST), juga mendukung hasil penelitian ini yang menyebutkan aktivitas fisik tidak mempengaruhi status hidrasi. ${ }^{21}$ Pada penelitian ini pengaruh status hidrasi lebih erat kaitannya dengan konsumsi cairan dibandingkan dengan aktivitas fisik. Walaupun aktivitas fisik pada remaja berat tetapi diimbangi dengan asupan cairan yang cukup, maka status hidrasi masih dalam kondisi baik. Begitu juga sebaliknya, walaupun aktivitas fisik ringan tetapi asupan cairan kurang maka remaja akan mengalami dehidrasi.

\section{SIMPULAN}

Obesitas dan konsumsi cairan yang kurang merupakan faktor risiko dehidrasi pada remaja. Remaja perlu meningkatkan konsumsi cairan agar sesuai dengan tingkat kebutuhan untuk mencegah kejadian dehidrasi. Khususnya, remaja obese yang memiliki kebutuhan cairan yang lebih besar dan risiko dehidrasi lebih besar jika dibandingkan dengan remaja non obese. Penelitian selanjutnya dapat dikembangkan suatu model intervensi untuk mencegah dehidrasi dan obesitas pda remaja. 


\section{UCAPAN TERIMAKASIH}

Penelitian ini didanai oleh hibah penelitian Riset Dosen Pemula (RDP) DIPA Fakultas Kedokteran Undip Tahun 2016.

\section{DAFTAR PUSTAKA}

1. Stang J. Adolescent Nutrition. In : Brown JE, editors. Nutrition Through the Life Cycle. $4^{\text {th }}$ ed. USA: Wardsworth Cengange Learning; 2011. p 357-384.

2. Badan Penelitian dan Pengembangan Kesehatan Kemenkes. Riset Kesehatan Dasar 2010. Jakarta .Kementrian Kesehatan RI. 2010. Hal 50-59.

3. Badan Penelitian dan Pengembangan Kesehatan Kemenkes. Riset Kesehatan Dasar 2013. Jakarta. Kementrian Kesehatan RI. 2013.

4. Muhammad D, Dieny FF. Hubungan asupan vitamin $\mathrm{A}, \mathrm{C}$, dan $\mathrm{E}$ dengan kejadian sindrom metabolik pada remaja obesitas. Journal of Nutrition College.2016; 5(4): 289-297.

5. Liu W, Lin R, Liu A, Du L,Chen Q. Prevalence and association between obesity and metabolic syndrome among chinese elementary school children: a school- based survey. Biomedical Central Journal. 2010;10: 1-7.

6. Prayitno SO, Dieny FF. Perbedaan konsumsi cairan dan status hidrasi pada remaja obesitas dan non obesitas. Journal of Nutrition Collage. 2012;1(1): 1-8.

7. Buanasita A, Andriyanto, Sulistyowati I. Perbedaan tingkat konsumsi energi, lemak, cairan dan status hidrasi mahasiswa obesitas dan non obese. Indonesian Journal of Human Nutrition. 2015; 2(1): 11-22.

8. Santoso BI, Hardinsyah, Siregar P, Pardede SO. Air Bagi Kesehatan. Jakarta: Centra Communication. 2011

9. Muckelbauer R, Sarganas G, Gruneis A, MullerNordhorn J. Association between water consumption and body weight outcomes: a systematic review. American Journal and Clinical Nutrition .2015; 98(2):282-299.

10. Whitney E, Rolfes SR. Water and The Major Minerals. In: Williams P, editors. Understanding Nutrition. $12^{\text {th }}$ ed. USA: Wadsworth Cengange Learning; 2011 p. 384-421

11. Daniels, Melissa C, barry M, Popkin. The impact of water intake on energy intake and weight status: a systemic review. Nutr Rev.2010; 68(9):505-521.

12. Marsetyo, Kartasapoetra. Korelasi Gizi, Kesehatan dan produktivitas kerja. Jakarta:Rineka Cipta;1995.

13. Susanti T, Astiti D, Paratmanitya Y. Hubungan pola konsumsi fast food denan kejadian obesitas pada remaja SMA Muhammadiyah 3 Yogyakarta. Universitas Alma ata. Naskah Publikasi. 2016
14. Kussoy K, Fatimawali, Kepel B. Prevalensi obesitas pada remaja di kabupaten Minahasa. Jurnal e-Biomedik (eBM). 2013;1(2): 981-985.

15. Perrier E, Vergne S, Klein A, Poupin M, Rondeou P. Hydration biomarkers in free-living adults with different levels of habitual fluid consumption. Br. J Nutr, $2013 ; 109$ : 1678-1687.

16. Hastuti YD, Nasution E, Aritonang E. Perilaku konsumsi air minum pada Siswa/ Siswi SMA Negeri 3 Medan Tahun 2015. Gizi, Kesehatan Reproduksi dan Epidemiologi. 2015;1(3): 1-6

17. Kleiner SM. Water : An essential but overlooked nutrient. J Am Diet Assoc. 1999;99:200-206.

18. Bird ET, Parker BD, Kim HS, Coffield SK. Caffeine ingestion and lower urinary tract symptoms in healthy volunteers. Neurourology and Urodynamics. 2005; 24: 611-615.

19. Killer SC, Blannin AK, Jeukendrup AE. No evidence of dehydration with moderate daily coffee intake : a counterbalanced cross over study in a free living population. PLoS ONE. 2014; 9(1); e84154.

20. Chang T, Ravi N, Plegue MA, Sonneville KR, Davis MM. Inadequate hydration, BMI, and obesity among US adults : NHANES 2009-2012. Ann Fam Med. 2016;14:320-324.

21. Gustam, Hardinsyah, Briawan D. Faktor Resiko Dehidrasi pada Remaja dan Dewasa. Bogor: Departemen Gizi Masyarakat FEMA IPB;2012

22. Hardinsyah, Soenaryo ES, Briawan D, Damayanthi E, Dwiriani CM, Effendi YH, Dewi M, Aries M. Studi Kebiasaan Minum \& Status Hidrasi pada Remaja dan Dewasa di Dua Wilayah Ekologi yang Berbeda. Bogor: Perhimpunan Peminat Gizi \& Pangan Indonesia (PERGIZI PANGAN INDONESIA), Departemen Gizi Masyarakat, Fakultas Ekologi Manusia, IPB Bogor. Danone Aqua Indonesia. 2009.

23. Stahl A, Kroke A, Bolzenius K, Manz F. Relation between hydration status in children and their dietary profile result from the DONALD study, Eur J Clin Nutr. 2007;61: 1386-1392.

24. O'Connell BN, Weinheimer EM, Martin BR, Weaver CM, Campbell WW. Water turnover assessment in overweight adolescents. Obesity. 2011; 19(2): 292-297.

25. Gordon RE, Kassier SM, Biggs C. Hydration status and fluid intake of urban, underprivileged south african male adolescent soccer players during training. Journal of International Society of Sport Nutrition. 2015;12(2): 1-10.

26. Putri RT, Jus'at I, Angkasa D. Pengetahuan tentang cairan, konsumsi cairan, IMT dan status hidrasi pada atlet marching band di Platda PON Banten 2016. Jakarta: Fakultas Ilmu Kesehatan, Universitas Esa Unggul. Repository;2016. 